MACHINE BUILDING

МАШИНОБУДУВАННЯ

UDC 621.941

A. Orgiyan, DSc., Prof.,

H. Oborskyi, DSc., Prof.,

A. Balaniuk, PhD, Assoc. Prof.,

I. Prokopovych, DSc., Assoc. Prof.

Odessa National Polytechnic University, 1 Shevchenko Ave., Odessa, Ukraine, 65044; e-mail: annabalanyuk24@gmail.com

\title{
EXPERIMENTAL RESEARCH OF CONSOLE BORING BARS OSCILLATIONS UPON FINE STEPPED HOLES BORING
}

\begin{abstract}
О.А. Оргіян, Г.О. Оборський, Г.В. Баланюк, І.В. Прокопович. Експериментальне дослідження коливань консольних борштанг при тонкому розточуванні ступінчастих отворів. Тонке розточування $є$ широко поширеним методом фінішної лезвийной обробки. При розточуванні ступінчастих отворів на практиці необхідно проектувати і виготовляти спеціальні ступінчасті консольні борштанги або багаторізцеві головки. В експериментах досліджені складні динамічні взаємодії, що виникають в технологічній системі при багаторізцевому розточуванні ступінчастими борштангами. Вивчено закономірності зміни амплітуд вимушених коливань при змінах параметрів пружної системи і процесів різання, зокрема, при змінах масо-геометричних характеристиках борштанг, жорсткостей та власних частот, довжин і діаметрів ступенів. Експерименти проводилися на експериментальних стендах, зібраних на базі обробно-розточувального верстата, оснащеного високоточної шпиндельною головкою 3 безступінчатим регулюванням швидкості обертання, i сучасної вимірювальною апаратурою. Виміри проводилися тензометричним методом, а також аналізатором спектру вібрацій 3 п'езодатчиком. Використовувалися двох і триступінчаті борштанги 3 різними масо-геометричними параметрами. Досліджувалися технологічні схеми обробки 3 обертовими та необертовими борштангами. В експериментах також варіювалися взаємне положення різців, глибини різання, що призводило до зміни значень коефіцієнтів впливу. Складні динамічні взаємодії при тонкому розточуванні ступінчастими борштанг при одночасній роботі різців призводять до немонотонної зміни амплітуд вимушених коливань, а вібросталість процесу розточування може або підвищуватися, або знижуватися. Практична значимість роботи дозволяє вирішити область застосування ступінчатих консольних борштанг шляхом вдосконалення їх проектування на основі не тільки статичних, але і динамічних розрахунків. Результати експериментальних досліджень покладені в основу теоретичного моделювання та розробку динамічних розрахункових моделей. Крім того, результати комплексного експериментального дослідження в науковому плані розвивають технологічну динаміку, як складову частину технології машинобудування.
\end{abstract}

Ключові слова: ступінчаста борштанга, розточний різець, амплітуда коливань, частота, вібросталість, технологічна динаміка

A. Orgiyan, H. Oborskyi, A. Balaniuk, I. Prokopovych. Experimental research of console boring bars oscillations upon fine stepped holes boring. Fine boring is a common way of finishing edge processing. Upon boring stepped hole, on practice it is necessary to design and produce special stepped console boring bars or multi-edged heads. In the experiments there were researched complicated dynamic interactions occurring in the technological system upon multi-edge boring with stepped boring bars. Regularities of forced oscillations amplitudes changes upon changes in flexible system parameters and cutting processes have been studied, namely upon changes in massgeometrical properties of boring bars, stiffness and own frequencies, variation of lengths and diameters of steps. Out-of-roundness of cross sections and roughness values of processed surfaces within the terms of simultaneous and separate work of edges have been researched. The experiments were carried out on machines assembled on the basis of a finishing and boring machine equipped with a high precision spindle head with rotation speed stepless regulation and modern measuring equipment. Measurements were carried out using strain gauge methods as well as a vibration spectrum analyzer with a piezo sensor. Two and three-stage boring rods with different mass geometry parameters were used. Processing diagrams with rotating and non-rotating boring rods were studied. Relative position of edges and cutting depths were also varied during experiments that led to change of values of impact indexes. Complex dynamic interactions at thin boring by step boring bars at simultaneous operation of picks lead to non-monotonous change of amplitudes of forced vibrations, and vibration stability of boring process can either increase or decrease. The practical importance of the work allows to solve the field of application of stepped console boring bars by improving their design on the basis of not only static, but also dynamic calculations. Results of experimental researches are put into basis of theoretical modelling and development of dynamic calculation models. In addition, the results of complex experimental research in scientific terms develop technological dynamics as a part of engineering technology.

Keywords: step boring bar, boring cutter, vibration amplitude, frequency, vibration resistance, technological dynamics

DOI: 10.15276/opu.1.60.2020.01

(C) 2020 The Authors. This is an open access article under the CC BY license (http://creativecommons.org/licenses/by/4.0/). 


\section{Introduction}

In this paper dynamic interactions at multi-edge fine boring of two- and three-step holes are researched.

The solution of dynamics problems in machining technology was reflected in the direction of technological dynamics as a component of machine-building technology.

At studying of the dynamic interactions arising in finishing-boring machines, it is necessary to pay special attention to the vibrations of the cantilever boring bars, installed on the spindle heads (the subsystem of the spindle of the boring bar), and also to study the influence on the vibrations of the parameters of the blank, installed in the fixture (the subsystem of the part - fixture) on the table of the machine. The level of vibrations during cutting is significantly determined by the parameters of these two subsystems and characterizes the relative movements of the edge and the blank unit, which ensure the quality of processing.

During researching of processes of fine boring and working out of settlement methods it is necessary to study potentially unstable forms of oscillations, to consider their physical manifestation, time and space forms. Complex dynamic interactions in the elastic-dissipative-inertial system in general cases represent a set of free, forced, parametric and auto oscillations. Each of these types of oscillations can be decisive under different processing conditions: for example, when boring complex surfaces of rotation, forced oscillations are typical, and when boring intermittent surfaces of rotation - parametric oscillations. When boring openings with a variable shear cross-section (cutting in the following direction), oscillations are generated. These self-excited oscillations lead, among others, to a sharp decrease in boring accuracy, loss of wear resistance of the edge and a decrease in productivity.

The quality of machining of precise holes, especially for thin multi-blade boring, can be improved by vibrations excited in the process system. The problem of damping mechanical vibrations is therefore still a very urgent one today.

\section{Analysis of last publications and problem statement}

The analysis of technical literature $[1,2]$ certifies a large number of experimental studies of different types of vibration, as well as achievements in the field of metal cutting based on the development and application of computational methods for the study of dynamic interactions in machine building technology.

Different physical models for the description of oscillations have been proposed by a number of well-known scientists: cutting on the trail from the previous pass (trace regeneration) [3] changes in the value of cutting force during the movement of the cutter in the metal and from it, the falling characteristic of cutting force from speed.

Changes in cutting speed and feed within the limits recommended for fine boring have less influence on the amplitudes of oscillation than changes in the boring bar length and cutting depth. The concept of vibration resistance of the machine is therefore characterized more by the stiffness of the boring bar than the ratio of length $l$ to its diameter $d$. Oscillations of long boring bars $(l / d \succ 3-4)$ are well described by differential equations of the 2 nd order in ordinary derivatives. At the same time, calculations of oscillations of long boring rods taking into account the dynamic characteristics of the cutting process $[4,5]$ allow to consider such system as single mass one and show that such dynamic system either has a small reserve of stability or goes into the auto-oscillation mode. The study of the oscillations of "long" boring bars is very important for determining the achievable machining accuracy without vibrating dampers.

Reducing the stiffness of the boring bars as the arm length increases leads to lower vibration resistance, higher vibration levels and increased tool wear. Peculiarities of boring bar vibrations have led to the necessity to study their dynamic characteristics, which is reflected in a large number of published papers [6 - 10].

The number of published in technical literature results of investigations on thin boring of stepped holes is relatively small, and in the majority of researches highlight the designs of multi-edge boring heads (or special boring bars) are discussed [11, 12]. In some papers vibration stability of boring process is characterized by the total specific cutting depth at absence of increased vibrations [13]. Dynamic features of boring two- and three-stage holes in the majority of published works are only mentioned 
or not considered at all, sources of excitation of vibrations, regularities of change of their amplitudes, and also changes of rigidity, own frequencies and geometrical parameters of boring bars impacting vibration stability are not studied.

In this paper [14] the study of the impact of dynamic effects of cutting on the errors of the shape of the hole under the influence of vibrations in the cutting process is carried out, errors of longitudinal and transverse sections are formally described, the necessity of research in the field of multi-cutter boring is emphasized, as well as the methodology for calculating the amplitudes of forced vibrations of the tool.

The development of the method with the purpose of improvement of the quality of holes boring in hull parts by way of directed combination of stiffening parameters of the technological system is described in [15].

Summarizing the results of the published research on boring of stepped holes, we note that the absence of the necessary scientific substantiation for the design of step boring bars prevents their implementation in the practice of metalworking.

The purpose of work is expansion of technological and dynamic possibilities of operations of multi-edge thin boring of stepped holes. For achievement of this purpose it is necessary to solve the following problems: to establish experimentally regularities of change of forced oscillations amplitudes of step boring bars upon separate and simultaneous operation of edges:

- to study the oscillations of rotating and non-rotating multicutting console borings bars;

- to study the impact of the edge arrangement on the level of oscillations during multi-edge boring.

Statement of the main material. In the experiments, samples made of steel 45, grey cast iron C436 (SCh36) and bronze were subject to boring. The samples were cylindrical bushings, on the inner surfaces of which stepped holes were made.

On Fig. 1 some constructions of boring bars used in experiments are shown.

Experiments were conducted in terms enabling to establish mutual impact of disturbance between the edges, intensity thereof, and also the quality of processing and error. The length of the samples made out $0.12 \ldots 0.25 \mathrm{~m}$, and the steps diameters $0.02 \ldots 0.10 \mathrm{~m}$. Blank units were fixed on spindle

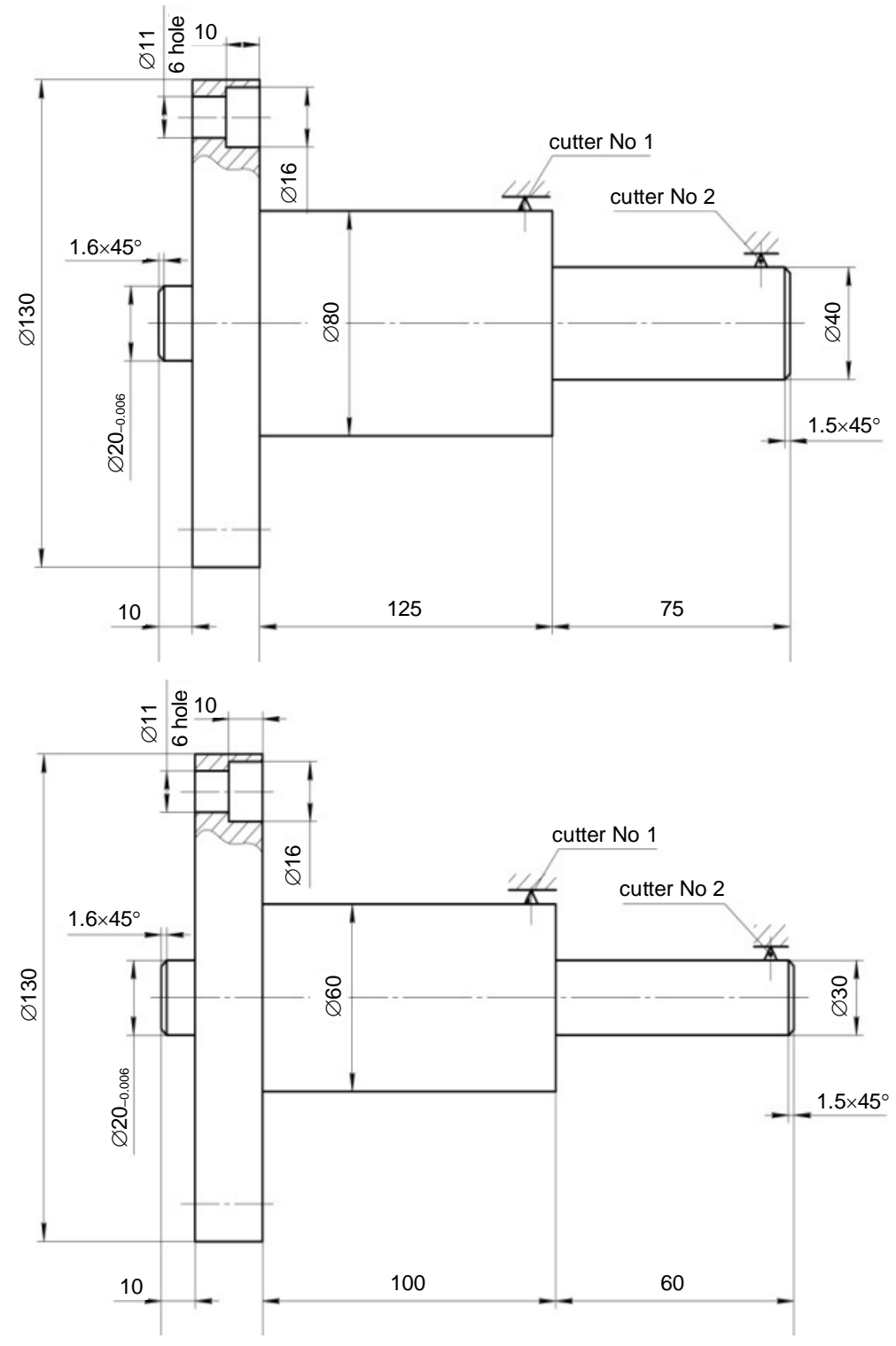

Fig. 1. Some Used Boring Bars 
heads of the first and second type of size.

In accordance with the data [16], in experiments the following geometry of edges cutting part used for fine boring of smooth surfaces was adopted:

- when boring steel: $\varphi=60^{\circ} ; \quad \varphi_{1}=10^{\circ} ; \quad \alpha=8^{\circ} ; \quad \alpha_{1}=12^{\circ} ; \gamma=-3^{\circ} ; \lambda=5^{\circ}$;

- when boring cast iron: $\varphi=60^{\circ} ; \varphi_{1}=10^{\circ} ; \quad \alpha=6^{\circ} ; \quad \alpha_{1}=10^{\circ} ; \quad \gamma=-5^{\circ} ; \quad \lambda=10^{\circ}$;

- when boring bronze: $\varphi=45^{\circ} ; \varphi_{1}=20^{\circ} ; \quad \alpha=10^{\circ} ; \alpha_{1}=8^{\circ} ; \gamma=0^{\circ} ; \lambda=10^{\circ}$.

Edges materials:

- when boring steel - T30K4, borazon;

- when boring cast iron - BK3M (VK3M);

- when boring bronze - edges with diamond crystals.

Cutting depth from 0.04 to $0.1 \mathrm{~mm}$, motion from $0.04 \ldots 0.12 \mathrm{~mm} / \mathrm{turn}$, speed from 100 to $200 \mathrm{~m} / \mathrm{min}$.

For each boring bar, static stiffness measurements were carried out in the two directions of $C_{y}$ and $C_{z}$ in the section of the most distant edge with a dynamometer with a gradation of $0.4 \mathrm{~N}$. The displacement was measured in the same cross section by the indicator mounted in the support. The natural frequency of the boring bar-device subsystem and the attenuation characteristic were based on oscillogram of the damping oscillations triggered by the impact in the edge's cross-section. In our exper-

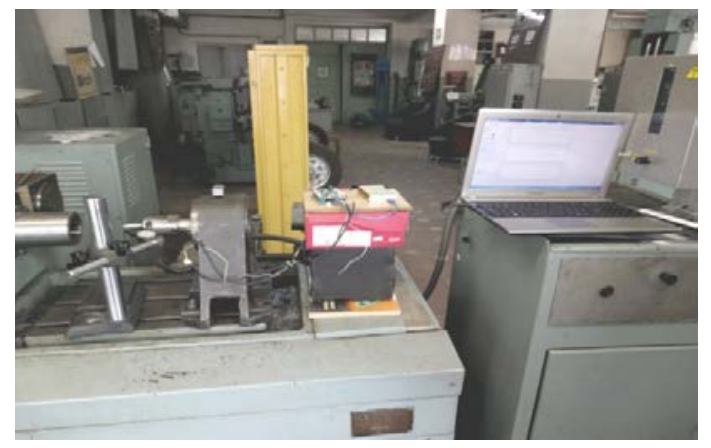

$a$
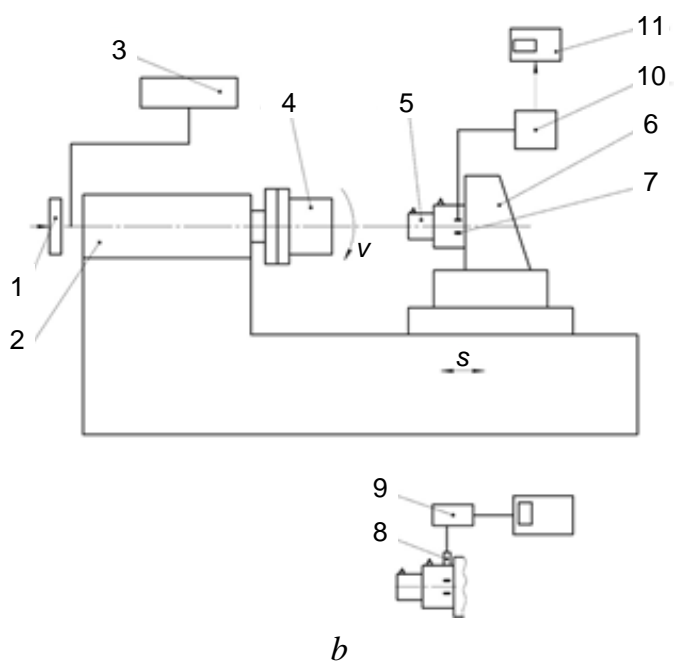

Fig. 2. Scheme of Experimental Stand for Researching Non-rotating Boring Bars:

1 - tachometer; 2 - spindle head; 3 - frequency converter; 4 - blank unit; 5 - boring bar;

6 - device; 7 - strain gauges; 8 - piezosensor;

9 - vibrations specter analyzer; 10 - oscillations recorder (OR); 11 - personal computer (PC) iments, the measured boring bars frequencies were between 200 and $1100 \mathrm{~Hz}$.

The boring was carried out with a batch of edges (6 pieces per batch) to avoid the influence of the geometrical characteristics of the individual edges. The re-installation criterion was an output of the sample surface by the roughness Ra of $0.9 \mu \mathrm{m}$. The surface roughness was determined by the profilograph.

The first group of experiments, carried out by non-rotating boring bars and aimed at studying vibrations upon boring one-, two- and three-stepped steel, cast iron and bronze samples, allowed to establish character of vibrations, influence of change of geometrical characteristics of step holes, depth and cutting speed on forced vibrations of borrows and accuracy of processing.

In the second group of experiments the oscillations of rotating boring rods at boring of step holes were studied. The blank units were made of steel, aluminum and bronze. To compare the amplitudes of vibrations at the same cutting speeds the samples were bordered at separately working edges and at their simultaneous work.

Oscillations of the rotating boring bar when boring two-stepped holes at varying cutting speeds were studied in the third group of experiments. The amplitudes of the vibrations were compared with the non-rotating boring bars.

Oscillations of rotating and non-rotating borings bars were studied on experimental stands. The general view of the stand (Fig. 2a) and its scheme (Fig. 2b) for the study of oscillations of the non-rotating boring rods are shown in Fig. 2. 
During the experiments, the processed blank unit (4) was mounted on the flange of the spindle head (2) of the FBM. The console boring bar (5) was fixed in the fixture (6), which is installed on the table of the machine. On the boring bar (5) near the mountings two pairs of strain gauges (7) were glued. Strain gauges (7) and OR (10) were used to measure the bending vibrations of the boring bar in two planes. Two pairs of strain gauges were included in the differential scheme and provided reliable measurement of the process in the frequency range of $0 \ldots 7000 \mathrm{~Hz}$. This frequency range is quite sufficient, since the featuring frequencies of bending vibrations of the boring bar are in the range of 400...3000 Hz.

The vibration recording device (10) consists of 4 strain gauges, which are connected to each other via a bridge circuit, microcontroller Discovery STM32L0538-DISCO, a strain amplifier, a microCD memory card and a Bluetooth radio module.

Oscillation recording device works as follows: the recorded analog signal at 4 strain gauges is recorded in the form of $n$ packets of data on a microCD memory card, which in turn is installed on the microcontroller Discovery, which allows you to increase the speed of the signal, while recording the full range of signal frequencies.

The special feature of the device design is that the signal is registered not with a PC, but with Discovery microcontroller STM32L0538-DISCO, which is controlled by a PC via Bluetooth radio module.

To visualize the calibration process, signal recording and processing, appropriate programs have been developed.

\section{Research results}

Some results from the first group of experiments are shown in Fig. 3.

Noteworthy, that in these experiments special features of dynamic interactions upon boring with two-stepped boring bar have been established: upon simultaneous work of two edges and proportion of lengths of steppes set to unit the amplitude of forced oscillations less than upon work of more distanced edge No. 2. This fact witnesses mutual damping of cutting processed given some parameters of boring bar and simultaneous work of two edges. At the same time, we noticed cases when increase of oscillations level upon simultaneous work of edges No. 1 and No. 2 in comparison with work of one edge No. 2 (see Table 1) took place. The mentioned experiment confirms the necessity of dynamic calculations upon designing two-stepped boring bars.

Impact of oscillations on roughness of processed surface and out-of-roundness is reflected in the Table 1.

Table 1

Experiments results

\begin{tabular}{c|c|c|c|c|c}
\hline $\begin{array}{c}\text { Boring bars } \\
\text { parameters }\end{array}$ & $\begin{array}{c}\text { Step } \\
\text { length } \\
l_{1}, \mathrm{~m}\end{array}$ & $\begin{array}{c}\text { Step length } \\
l_{2}, \mathrm{~m}\end{array}$ & $\begin{array}{c}\text { Oscillations } \\
\text { amplitude, } \\
A, \mu \mathrm{m}\end{array}$ & $\begin{array}{c}\text { Roughness } \\
\text { Ra, } \mu \mathrm{m}\end{array}$ & $\begin{array}{c}\text { Out-of-roundness } \\
\Delta R, \mu \mathrm{m}\end{array}$ \\
\hline & 0.14 & 0.02 & 0.3 & 0.3 & 0.65 \\
\cline { 2 - 6 } & 0.12 & 0.04 & 0.55 & 0.3 & 1.15 \\
\cline { 2 - 6 }$d_{1}=0.06 \mathrm{~m}$, \\
$d_{2}=0.03 \mathrm{~m}$, \\
\cline { 2 - 6 }$=0.16 \mathrm{~m}$
\end{tabular}

Results of the second group of experiments on measuring oscillations of rotating boring bars show that rotating of cutting zone leads to some increase of oscillations intensity by amplitudes, though regularities in measuring them are the same as in the first group.

Results of the third group experiments provide for making conclusion that upon boring with differently facing edges the dynamic interactions like upon unidirectional edges can make both positive 
and negative impact on the level of forced oscillations. In each individual case the changes in the oscillation levels result from statistical and dynamic parameters of elastic system, cutting process and external disturbances.

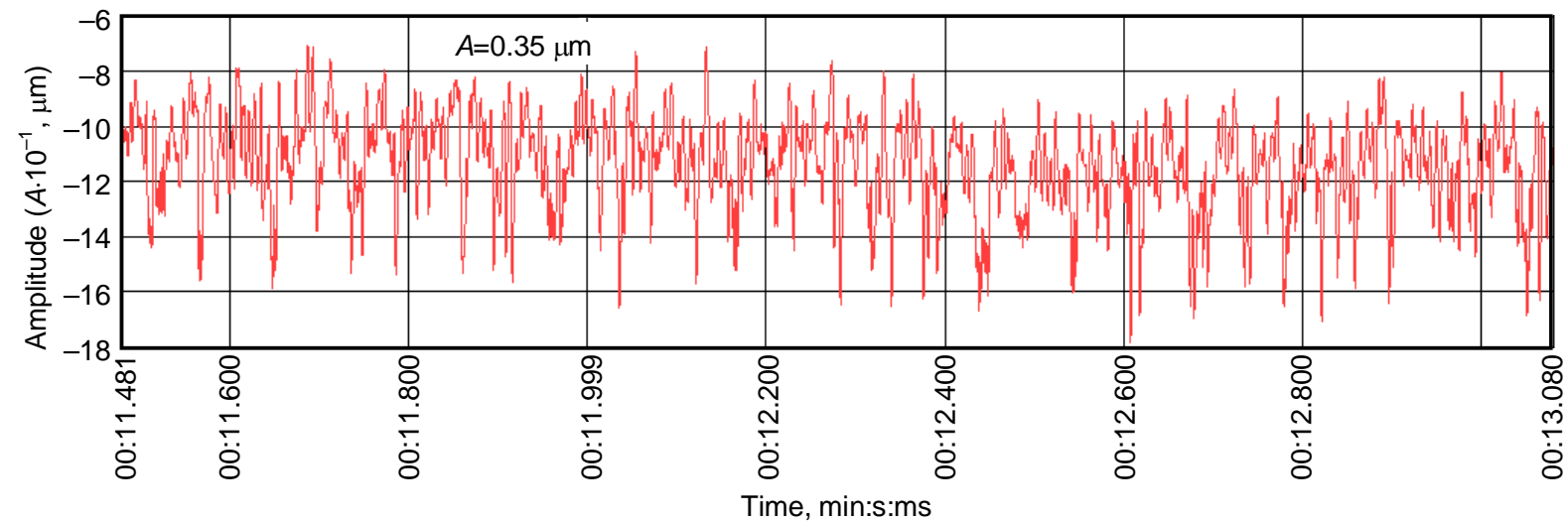

$a$

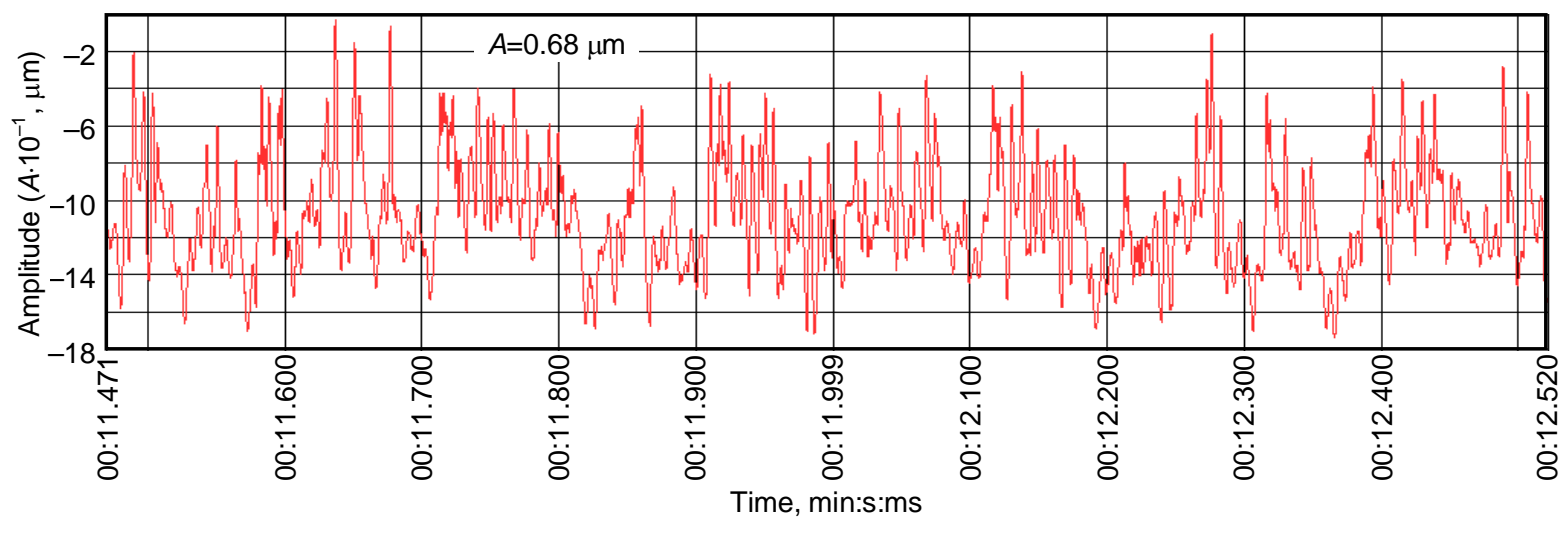

$b$

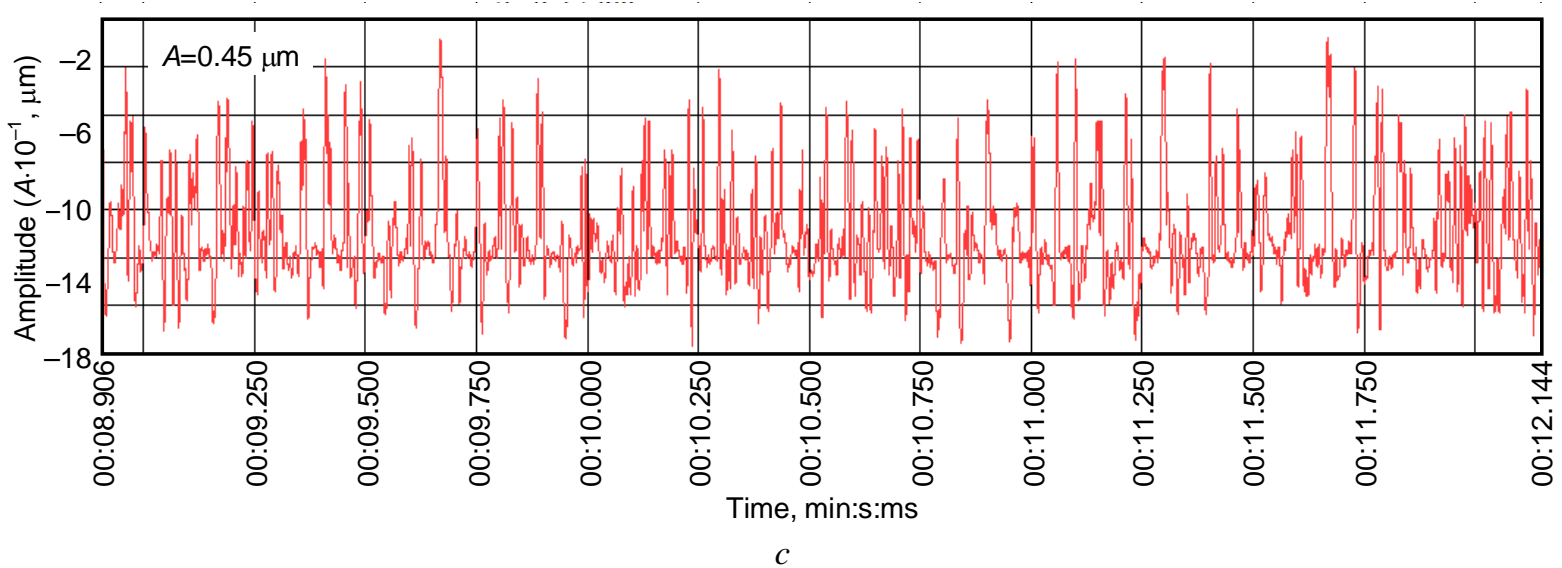

Fig. 3. Operation Amplitudes Oscillograms for Edge No. 1 (a), No. 2 - (b) and upon simultaneous work of edges No. 1 and No. 2 (c); $L=0.15 \mathrm{~m}, l_{1}=0.075 \mathrm{~m}, l_{2}=0.075 \mathrm{~m}, d_{1}=0.06 \mathrm{~m}, d_{2}=0.04 \mathrm{~m}$, processed material steel 45, cutting modes: $n=1250 \mathrm{rpm}, \mathrm{s}=0.09 \mathrm{~mm} / \mathrm{r}, t_{1}=t_{2}=0.05 \mathrm{~mm}$.

The Table 2 shows experimental values of forced oscillations amplitudes, roughness and out-ofroundness upon simultaneous work with oppositely under the angle $180^{\circ}$ installed edges with changes in steppes length 
Experimental Values of Forced Oscillations Amplitudes, Roughness and Out-of-Roundness upon Simultaneous Work with Oppositely under the Angle $180^{\circ}$ Installed Edges with Changes in Steppes Length

\begin{tabular}{c|c|c|c|c|c}
\hline $\begin{array}{c}\text { Boring bars } \\
\text { parameters }\end{array}$ & $\begin{array}{c}\text { Step length } \\
l_{1}, \mathrm{~m}\end{array}$ & $\begin{array}{c}\text { Step length } \\
l_{2}, \mathrm{~m}\end{array}$ & $\begin{array}{c}\text { Oscillations } \\
\text { amplitude, } \\
A, \mu \mathrm{m}\end{array}$ & $\begin{array}{c}\text { Roughness } \\
\text { Ra, } \mu \mathrm{m}\end{array}$ & $\begin{array}{c}\text { Out-of- } \\
\text { roundness } \\
\Delta R, \mu \mathrm{m}\end{array}$ \\
\hline & 0.12 & 0.04 & 0.26 & 0.6 & 1.1 \\
\cline { 2 - 6 }$d_{1}=0.08 \mathrm{~m}$, & 0.1 & 0.06 & 0.17 & 0.5 & 1.0 \\
\cline { 2 - 6 }$d_{2}=0.04 \mathrm{~m}$, \\
\begin{tabular}{c}
$l=0.16 \mathrm{~m}$ \\
\cline { 2 - 6 }
\end{tabular} & 0.08 & 0.08 & 0.24 & 0.6 & 1.1 \\
\cline { 2 - 6 } & 0.06 & 0.1 & 0.3 & 0.75 & 1.2 \\
\hline
\end{tabular}

Same results were gained in the experiments with multidirectional edges set under the angles $90^{\circ}$ and $150^{\circ}$.

Comparison of polar diagrams of processed holes with multidirectional edges in all checked experiments showed that out-of-roundness having the shape of oval lead to their turn in relation to each other in various steppes of the processed holes. Various orientation of ovals axes in cross sections of hole steppes eventually results into decrease of the quality of assembly and operation of these parts.

\section{Conclusions}

1. Upon simultaneous work inter-impact of edges leads to increase or decrease of the level of forced oscillations depending on design parameters of boring bar (steppes diameters to lengths ratio) and processing modes.

2. Results of experiments with rotating boring bars confirms main regularities of dynamic interactions occurring upon boring with non-rotating boring bars, though the intensity of oscillation amplitudes somehow increase.

3. Experiments on studying the dynamics of boring sample units with oppositely under the angle $180^{\circ}$ installed boring bars showed that such alignment can lead both to decrease and increase of oscillations amplitudes.

4. Changes in parameters of cutting processes (cutting indexes, processed materials, spindle rotation frequency) lead to increase or decrease of vibration resistance of the technological system.

5. Cross section accuracy and roughness parameters vary in accordance with the increase of forced oscillations.

6. Results of held experiments confirm the fact that estimation of oscillation levels upon designing stepped boring bars requires dynamic calculations in each individual case.

\section{Література}

1. Внуков Ю.Н. Определение динамических характеристик нежестких деталей типа защемленных пластин. Сучасні технологіi в машиноборудованні. 2011. Вип. 6. С. 6-12.

2. Оборский Г.А., Паленный Ю.Г., Оргиян Андр.А. Возбуждение изгибно-крутильных колебаний и их измерения на вращающихся консольных инструментах. Вістник ХНУ, Технічні науки. 2016. № 1. C. 146-149.

3. Zaloga W., Shapoval Y., Kolesnyk V. Increasing of efficiency of parts turning al spindle speed from 5.000 to 10.000 rpm by controlling the dynamics of machining / Monograph: Quality and reliability of technical systems: theory and practice / Editors: Andrii Goroshko, Vilen Royzman, Maryna Zembytska. JVE International Ltd., Lithuania. 2018. Vol. 2. P. 90-102. ISSN 2351-5260, ISBN 978-609-96036-0-5.

4. Grossi N., Croppi L., Scippa A., Campatelli, G. A dedicated design strategy for active boring bar. Applied Sciences. 2019. 9(17). 3541. DOI: https://doi.org/10.3390/app9173541.

5. Ren Y., Zhao Q., Liu Y., Ma J. Analysis of bending vibration characteristics of rotating composite boring bar. Journal of Physics: Conference Series. 2019. 1303. DOI:10.1088/1742-6596/1303/1/012147. 
6. Bansal A., Law M. A Receptance Coupling Approach to Optimally Tune and Place Absorbers on Boring Bars for Chatter Suppression. 8th CIRP Conference on High Performance Cutting (HPC 2018). 2018. Vol. 77. P. 167-170. DOI: https://doi.org/10.1016/j.procir.2018.08.267.

7. Yang Y., Munoa J., Altintas Y. Optimization of multiple tuned mass dampers to suppress machine tool chatter. Int. J. of Mach. Tools and Mfg. 2010. 50 (9). P. 834-842.

8. Bansal A., Law M. A Receptance Coupling Approach to Design Damped Boring Bars. COPEN 10. 2017. P. 798-801.

9. Lijia Liu, Xianli Liu, Yuanhong Liu. Non-uniform sampling finite-time control for networked control systems via event-driven transmission. Advances in Mechanical Engineering. 2016. Vol. 8(4). P. 1-10.

10. Amato F., Ariola M., Cosentino C. Finite-time stability of linear time-varying systems: analysis and controller design. IEEE Transactions on Automatic Control. 2010. 55 (4). P. 1003-1008. DOI: 10.1109/TAC.2010.2041680

11. Knut Sørby, Dan Østling. Precision turning with instrumented vibration-damped boring bars. 8th CIRP Conference on High Performance Cutting (HPC 2018). 2018. Vol. 77. P. 666-669. DOI: https://doi.org/10.1016/j.procir.2018.08.181.

12. Analysis and predictionon the cutting process of constrained damping boring bars based on PSO-BP neural network model / Xianming Chen, Tieliu Wang, Mingming Ding, Jing Wang, Jianqing Chen, Jun Xia Yan. Journal of vibroengineering. 2017. Vol. 19, Is. 2. P. 878-893. DOI: 10.21595/jve.2017.18068.

13. Брижан Т.М. Условия повышения точности обработки отверстий. Инновации, качество и сервис в технике и технологиях: сб. науч. тр. 4-ой международ. науч.-практ. конф. В 3-х томах, Том 1. Курск : Юго-Зап. гос. ун-т, 2014. С. 104-109.

14. Кочанов Ю.С. Алмазно-расточные станки. Источники погрешностей при тонком растачивании. Фундаментальные и прикладные проблемы техники и технологии. Орловский государственный университет им. И.С. Тургенева. 2014. № 6(308). С. 82-85.

15. Родионова Н.А. Оценка отклонений формы цилиндрических поверхностей собираемых деталей. Сборка в машиностроение. 2004. № 11. С. 9-12.

16. Основы теории резания материалов: учебник / Н.П. Мазур, Ю.Н. Внуков, А.И. Грабченко и др. Под общ. ред. Н.П. Мазура и А.И. Грабченко. 2-е изд., перераб. и дополн. Харьков : НТУ «ПИ», 2013. 534 c.

\section{References}

1. Vnukov, Yu.N., (2011). Finding Dynamic Properties of Non-rigid Parts Like Jammed Plates. Modern tehcnologies in machine building, 6, 6-12.

2. Oborskyi, H.A., Palennyi, Yu.H, \& Orhiian, Andr. (2016). A Triggering Bending-Rotating Oscillation and Measurement Thereof on Rotating Console Tools. Technical Sciences. Vistnyk KNU. - Khmelnytskyi, 1, 146-149.

3. Zaloga, W., Shapoval, Y., \& Kolesnyk, V. (2018). Increasing of efficiency of parts turning al spindle speed from 5,000 to $10.000 \mathrm{rpm}$ by controlling the dynamics of machining. Monograph. Quality and reliability of technical systems: theory and practice. Andrii Goroshko, Vilen Royzman, Maryna Zembytska (Ed.); JVE International Ltd., Lithuania, 2, 90-102. ISSN 2351-5260, ISBN 978-609-96036-0-5.

4. Grossi, N., Croppi, L., Scippa, A., \& Campatelli, G. (2019). A dedicated design strategy for active boring bar. Applied Sciences, 9(17), 3541. DOI: https://doi.org/10.3390/app9173541.

5. Ren, Y., Zhao, Q., Liu, Y., \& Ma, J. (2019). Analysis of bending vibration characteristics of rotating composite boring bar. Journal of Physics: Conference Series, 1303. DOI:10.1088/17426596/1303/1/012147.

6. Bansal, A \& Law, M. (2018). A Receptance Coupling Approach to Optimally Tune and Place Absorbers on Boring Bars for Chatter Suppression. 8th CIRP Conference on High Performance Cutting, 77, 167-170. DOI: https://doi.org/10.1016/j.procir.2018.08.267.

7. Yang, Y., Munoa, J. \& Altintas, Y. (2010). Optimization of multiple tuned mass dampers to suppress machine tool chatter. Int. J. of Mach. Tools and Mfg., 50 (9), 834-842.

8. Bansal, A. \& Law, M. (2017). A Receptance Coupling Approach to Design Damped Boring Bars. COPEN 10, 798-801.

9. Lijia, L., Xianli, L. \& Yuanhong, L. (2016). Non-uniform sampling finite-time control for networked control systems via event-driven transmission. Advances in Mechanical Engineering, 8(4), 1-10.

10. Amato, F., Ariola, M., \& Cosentino, C. (2010). Finite-time stability of linear time-varying systems: analysis and controller design. IEEE Transactions on Automatic Control, 55 (4), 1003-1008. DOI: 10.1109/TAC.2010.2041680. 
11. Knut, S., \& Dan, Ø. (2018). Precision turning with instrumented vibration-damped boring bars. 8th CIRP Conference on High Performance Cutting (HPC 2018), 77, 666-669. DOI: https://doi.org/10.1016/j.procir.2018.08.181.

12. Xianming, C., Tieliu, W., Mingming, D., Jing, W., Jianqing, C., \& Jun, X. Y. (2017). Analysis and predictionon the cutting process of constrained damping boring bars based on PSO-BP neural network model. Journal of vibroengineering, 19, 2, 878-893. DOI: 10.21595/jve.2017.18068.

13. Brizhan, T.M. (2014). Conditions for Increase of Holes Processing Accuracy Innovation, Quality and Service in Machinery and Technologies, 1, 104-109.

14. Kochanov, Yu. S. (2014). Diamond-Boring Machine. Sources of Errors upon Fine Boring. Fundamental and Applied Problems of Machines and Technology, 6(308), 82-85.

15. Rodionova, N.A. (2004). Estimation of Cylindrical Surfaces Shape Errors of Assembled Parts. Sborka $v$ mashinostroyeniye, 11, 9-12.

16. Mazur, N.P., Vnukov, Yu.N, \& Hrabchenko, A.I. et al. (2013). Basics of Materials Cutting Theory: Handbook. N.P. Mazur, A.I. Hrabchenko (Ed.) $2^{\text {nd }}$ edition, reworked and added. Khar'kov: NTU«KHPI».

Оргіян Олександр Андрійович; Orgiyan Alexander, ORCID: 0000-0002-1698-402X

Оборський Геннадій Олександрович; Oborskyi Gennadiy, ORCID: 0000-0002-5682-4768

Баланюк Ганна Василівна; Balaniuk Anna, ORCID: 0000-0003-1628-0273

Прокопович Ігор Валентинович; Prokopovych Ihor, ORCID: https://orcid.org/0000-0002-8059-6507

Received January 15, 2020

Accepted February 21, 2020 